Journal of Extension Education

Vol. 29 No. 4, 2017

DOI:https: / / doi.org/10.26725/JEE.2017.4.29.5966-5971

\title{
Social Exclusion of Tribal Agricultural Labourers of Kerala
}

\section{Dhanusha Balakrishnan ${ }^{1}$ and Preethu K Paul ${ }^{2}$}

\begin{abstract}
The literacy rate and standard of living of the tribal people in Wayanad district in Kerala is still very low and constant efforts are being made by the State government and Central government to improve their conditions. The present study was conducted during 2016-17 in districts of Thirunelly, Mananthavady and Panamaram panchayats. From each panchayat, 30 tribal women and 10 men agricultural labourers were selected making to a total of 120 respondents. The study shows that majority of the tribal women experienced high level of geographic, economic and political legal exclusion.
\end{abstract}

Keywords : Tribe; Adiya; geographic exclusion; economic exclusion; political exclusion; socio cultural exclusion; Kerala

\section{INTRODUCTION}

The total population in Wayanad district of Kerala as per the 2011 census was 816558 and the scheduled tribe population forms $18.5 \%$ of the total population i.e. 151443. There are approximately 3200 tribal colonies in Wayanad. Literacy rate and standard of living of the tribal people is still very low and constant efforts are made by the State and Central governments to improve their conditions. The major tribal groups in Wayanad are Adiya, paniya and the kurichians.

\section{The Adiyan or ravulayar tribe}

Adiya belong to the slave tribal sector of Kerala. In a typical 'adiya' family, husband is the head of the household. Divorce, widow marriage and polygamy are also practiced. The tribal community of 'Adiyan' is divided into 20 classes called as 'Mandu'. The head of each 'Mandu' is called as 'Chommikkaran' or 'Peruman'. Different from the non tribal communities, bride price is given to the parents of the bride from the groom.

The 'adiyans' prefer themselves to be called as ravular and they belong to the slave tracts of Wayanad. They are linguistically and ethnically related to the 'Ravula' language speaking 'Yerava' tribe in the neighbouring Coorg district of Karnataka (Prabhu,2011). They are mostly agricultural labourers but as the agricultural fields are depleting they

$1 \& 2$ Asst. Professors (Contract) Department of Agricultural Extension, College of Agriculture, Vellayani, Kerala Agricultural University, Thrissur, Kerala, India 
are giving up agriculture and are now taking up jobs such as construction work and daily wage labours. Women are active members of Mahatma Gandi National Rural Employment Guarantee Programme. The only agricultural work they do now is in coffee, tea and ginger plantations.

Even though there are a number of constitutional safeguards and governmental policies to bring the tribal people to the mainstream and to prevent the atrocities against them they still lack basic amenities. Moreover they also face difficulty in enjoying the basic rights of a citizen. Their security is still challenged and many are under the vicious grip of indebtedness and alcoholism. This study explores the social exclusion of the Adiyan tribe, in detail.

\section{METHODOLOGY}

In this study social exclusion is operationally defined as a multidimensional process of progressive social rupture, detaching groups and individuals from social relations and institutions and preventing them from full participation in the normal, normatively prescribed activities of the society in which they live.

Generally, four categories of exclusion have been faced by the tribes. They are Geographical exclusion, Economical exclusion, Political-legal exclusion and Socio-cultural exclusion.

The variable was measured by modifying the scoring procedure developed by Anoop (2013).

The scores given are:

\begin{tabular}{|c|c|c|c|c|}
\hline $\begin{array}{c}\text { Strongly } \\
\text { felt }\end{array}$ & Felt & $\begin{array}{c}\text { Unde } \\
\text { cided }\end{array}$ & $\begin{array}{c}\text { Not } \\
\text { felt }\end{array}$ & $\begin{array}{c}\text { Not at } \\
\text { all felt }\end{array}$ \\
$(5)$ & $(4)$ & $(3)$ & $(2)$ & $(1)$ \\
\hline
\end{tabular}

\section{FINDINGS AND DISCUSSION}

Social exclusion is the process in which members of a group are excluded or denied access to the services and resources which are normally available to the members of another group. In this study the exclusion is analysed under the categories namely geographical, political, socio-cultural and political.

Geographic exclusion is mainly due to the remote geographic location of the groups. Mainly due to this hurdle, basic services such as schools, hospitals and credit institutions are often inaccessible to the tribal people. This is directly correlated to social exclusion as lack of basic infrastructure and services is one major reason that leads to social exclusion.

Political rights and awareness about their rights is the basic need of every citizen. But when a group of people is excluded from enjoying their rights because of the caste, race or gender they belong to, that leads to political exclusion which is another factor that can cause social exclusion.

Economic exclusion is when a group of people is excluded on the basis 
of the income or on the basis of their financial status. This adversely affects his everyday life and there is a tendency among the non tribals to exploit them further more by giving them lower wages and incentives. This acts as a barrier before their dreams and goals leading to Economic exclusion.

Socio cultural exclusion may be the end result of dominance of several other cultures and languages that are alien to them virtually creating a world that is unfamiliar to the tribal people. This drags the tribal people away from their roots, and leaves them marginalized. Socio cultural exclusion arises when the tribal people are not allowed to mingle with the outside world and they are restricted in taking decisions of their interest. When the tribal people move away from their cultural roots, they are exposed to a condition that is alien to them, this will again make them excluded from the so called main stream. For this situation to be changed the attitude of the non tribals towards them should also be changed.

\section{Geographic Exclusion}

Table 1 shows the distribution of respondents based on geographic exclusion.

From the table it could be seen that $98.33 \%$ of the females and 90\% of the male respondents in Thirunelly panchayat experienced high level of geographic exclusion while only $6.67 \%$ of the females and $10 \%$ of the males said that they experience low level of geographic exclusion. In the case of Mananthavady panchayat, $80 \%$ of the females, and $50 \%$ of the males experience high level of geographic exclusion and another $50 \%$ of the males experience low level of geographic exclusion. In the case of Panamaram, 100\% of both males and females experience low level of geographic exclusion.

The higher level of geographic exclusion in Thirunelly and Mananthavady panchayat might be mainly due to the remoteness of the areas and lack of infrastructure like roads and transportation facilities

Table 1.

Distribution of Respondents based on Geographic Exclusion

\begin{tabular}{|c|c|c|c|c|c|c|c|c|c|c|c|c|c|}
\hline \multirow{3}{*}{$\begin{array}{l}\text { S1. } \\
\text { No }\end{array}$} & \multirow{3}{*}{ Category } & \multicolumn{4}{|c|}{ Thirunelly } & \multicolumn{4}{|c|}{ Mananthavady } & \multicolumn{4}{|c|}{ Panamaram } \\
\hline & & \multicolumn{2}{|c|}{ Female } & \multicolumn{2}{|c|}{ Male } & \multicolumn{2}{|c|}{ Female } & \multicolumn{2}{|c|}{ Male } & \multicolumn{2}{|c|}{ Female } & \multicolumn{2}{|c|}{ Male } \\
\hline & & $\mathbf{F}$ & $\%$ & $\mathbf{F}$ & $\%$ & $\mathbf{F}$ & $\%$ & $\mathbf{F}$ & $\%$ & $\mathbf{F}$ & $\%$ & $\mathbf{F}$ & $\%$ \\
\hline 1. & $\begin{array}{l}\text { Below } \\
12 \text { (low) }\end{array}$ & 2 & 6.67 & 1 & 10 & 6 & 20 & 5 & 50 & 30 & 100 & 10 & 100 \\
\hline 2. & $\begin{array}{l}\text { Above } \\
12 \text { (high) }\end{array}$ & 28 & 98.33 & 9 & 90 & 24 & 80 & 5 & 50 & 0 & 0 & 0 & 0 \\
\hline
\end{tabular}


to these areas. Low level of geographic exclusion in Panamaram panchayat might be due to the proximity of the tribal hamlets to the city with proper transportation facilities.

\section{Economic Exclusion}

Table 2 shows the distribution of respondents based on Economic exclusion.

In the case of economic exclusion,

Table 2.

Distribution of Respondents based on Economic Exclusion

\begin{tabular}{|c|c|c|c|c|c|c|c|c|c|c|c|c|c|}
\hline \multirow{3}{*}{$\begin{array}{l}\text { S1. } \\
\text { No }\end{array}$} & \multirow{3}{*}{ Category } & \multicolumn{4}{|c|}{ Thirunelly } & \multicolumn{4}{|c|}{ Mananthavady } & \multicolumn{4}{|c|}{ Panamaram } \\
\hline & & \multicolumn{2}{|c|}{ Female } & \multicolumn{2}{|c|}{ Male } & \multicolumn{2}{|c|}{ Female } & \multicolumn{2}{|c|}{ Male } & \multicolumn{2}{|c|}{ Female } & \multicolumn{2}{|c|}{ Male } \\
\hline & & $\mathbf{F}$ & $\%$ & $\mathbf{F}$ & $\%$ & $\mathbf{F}$ & $\%$ & $\mathbf{F}$ & $\%$ & $\mathbf{F}$ & $\%$ & $\mathbf{F}$ & $\%$ \\
\hline 1. & $\begin{array}{l}\text { Below } 30 \\
\text { (low) }\end{array}$ & 3 & 10 & 0 & 0 & 3 & 10 & 1 & 10 & 25 & 83.3 & 8 & 80 \\
\hline 2. & $\begin{array}{l}\text { Above } 30 \\
\text { (high) }\end{array}$ & 27 & 90 & 10 & 100 & 27 & 90 & 9 & 90 & 5 & 16.6 & 2 & 20 \\
\hline
\end{tabular}

$90 \%$ of the females and $100 \%$ of the males experienced high level of economic exclusion in Thirunelly panchayat, and about $10 \%$ of the females felt that they experienced low level of economic exclusion. In the case of Mananthavady panchayat, $90 \%$ of the males and females experienced high level of economic exclusion. $10 \%$ of both males and females experienced low level of economic exclusion. In the case of Panamaram panchayat $83.3 \%$ of the females and $80 \%$ of the males experienced low level of economic exclusion. $16 \%$ of the females and $20 \%$ of the males said that they experienced high level of economic exclusion.

Economic exclusion might be due to the low level of economic status. They are not treated indifferently during the financial transactions if they have money in their hands. But the situation might be different if their economic status is low. Economic exclusion was severely faced by women as they are paid unequal wages and are not given timely incentives. This kind of economic exclusion is a major detrimental factor that hinders development.

\section{Socio cultural Exclusion}

Table 3 shows the distribution of respondents based on socio cultural exclusion.

On examining the data of socio cultural exclusion, it can be found that $73.33 \%$ of the females and $80 \%$ of the males in Thirunelly panchayat, faced high level of socio cultural exclusion while $26.6 \%$ of the females and $20 \%$ of 
Table 3.

Distribution of Respondents based on Socio - cultural Exclusion

\begin{tabular}{|c|c|c|c|c|c|c|c|c|c|c|c|c|c|}
\hline \multirow{3}{*}{$\begin{array}{l}\text { S1. } \\
\text { No }\end{array}$} & \multirow{3}{*}{ Category } & \multicolumn{4}{|c|}{ Thirunelly } & \multicolumn{4}{|c|}{ Mananthavady } & \multicolumn{4}{|c|}{ Panamaram } \\
\hline & & \multicolumn{2}{|c|}{ Female } & \multicolumn{2}{|c|}{ Male } & \multicolumn{2}{|c|}{ Female } & \multicolumn{2}{|c|}{ Male } & \multicolumn{2}{|c|}{ Female } & \multicolumn{2}{|c|}{ Male } \\
\hline & & $\mathbf{F}$ & $\%$ & $\mathbf{F}$ & $\%$ & $\mathbf{F}$ & $\%$ & $\mathbf{F}$ & $\%$ & $\mathbf{F}$ & $\%$ & $\mathbf{F}$ & $\%$ \\
\hline 1. & \begin{tabular}{|l} 
Below \\
12 (low)
\end{tabular} & 8 & 26.6 & 2 & 20 & 28 & 93.33 & 9 & 90 & 29 & 96.67 & 10 & 100 \\
\hline 2. & \begin{tabular}{|l} 
Above \\
12 (high)
\end{tabular} & 22 & 73.3 & 8 & 80 & 2 & 20 & 1 & 10 & 1 & 3.33 & 0 & 0 \\
\hline
\end{tabular}

the males experienced low level of socio cultural exclusion. In Mananthavady panchayat, $93.33 \%$ of the females and $90 \%$ of the males experienced low level of socio cultural exclusion, $20 \%$ of the females and $10 \%$ of the males experienced high level of socio cultural exclusion.

In the Panamaram panchayat, $96.67 \%$ of the females and $100 \%$ of females experienced low level of socio cultural exclusion. Only $3.33 \%$ of the females experienced high level of socio cultural exclusion. Higher level of socio cultural exclusion in Thirunelly panchayat might be due to the age old traditions they follow and the main reason might be due to the sceptical attitude of the non tribals residing in the area.

\section{Political Legal Exclusion}

Table 4 shows the distribution of respondents based on political legal exclusion

Political legal exclusion in the case of Thirunelly panchayat was recorded with $90 \%$ females and $80 \%$ of the males experiencing high level of political legal exclusion. In Mananthavady panchayat $86.6 \%$ of the females and $90 \%$ of the males experienced high level of political legal exclusion. In the case of Panamaram panchayat, $86.6 \%$ of the females and $50 \%$ of the males experienced high level of political legal exclusion. $13.3 \%$ of the females and $50 \%$ of the males of the Panamaram panchayat experienced low level of political legal exclusion. High level of political legal exclusion might be due to the low political orientation and mobility among the tribal communities. They were mainly unaware about their rights and therefore they got exploited by the non tribal people. There was even an instance where the land allotted to the tribals was procured by the non tribals using illegal means. The tribal people did not respond as they were unaware of the legal protection provided to them by the constitution. 
Table 4.

Distribution of respondents based on Political - Legal Exclusion

\begin{tabular}{|c|c|c|c|c|c|c|c|c|c|c|c|c|c|}
\hline \multirow{3}{*}{$\begin{array}{l}\text { S1. } \\
\text { No }\end{array}$} & \multirow{3}{*}{ Category } & \multicolumn{4}{|c|}{ Thirunelly } & \multicolumn{4}{|c|}{ Mananthavady } & \multicolumn{4}{|c|}{ Panamaram } \\
\hline & & \multicolumn{2}{|c|}{ Female } & \multicolumn{2}{|c|}{ Male } & \multicolumn{2}{|c|}{ Female } & \multicolumn{2}{|c|}{ Male } & \multicolumn{2}{|c|}{ Female } & \multicolumn{2}{|c|}{ Male } \\
\hline & & $\mathbf{F}$ & $\%$ & $\mathbf{F}$ & $\%$ & $\mathbf{F}$ & $\%$ & $\mathbf{F}$ & $\%$ & $\mathbf{F}$ & $\%$ & $\mathbf{F}$ & $\%$ \\
\hline 1. & $\begin{array}{l}\text { Below } \\
12 \text { (low) }\end{array}$ & 3 & 10 & 2 & 20 & 4 & 13.3 & 1 & 10 & 4 & 13.3 & 5 & 50 \\
\hline 2. & $\begin{array}{l}\text { Above } \\
12 \text { (high) }\end{array}$ & 27 & 90 & 8 & 80 & 26 & 86.6 & 9 & 90 & 26 & 86.6 & 5 & 50 \\
\hline
\end{tabular}

\section{CONCLUSION}

From the study it can be concluded that, majority of the females and males of Thirunelly panchayat experienced high level of geographic exclusion. In the case of economic exclusion Mananthavady and Thirunelly panchayat experienced high level of economic exclusion In the case of socio cultural exclusion, Tirunelly experienced high level of socio cultural exclusion.

In the case of political legal exclusion, majority of the females and males of Thirunelly panchayat experienced high level of political legal exclusion, in the Mananthavady panchayat majority belonged to the high level of political legal exclusion and in the Panamaram panchayat also females and males also experienced high political legal exclusion. The tribes form a major part in Wayanad and it is essential that they are not excluded from the mainstream. Designing and implementing inclusive developmental programmes will reduce the wide gap between tribes and nontribes.

\section{REFERENCES}

Anoop, R. J. (2013). Social exclusion of tribal agricultural labourers: the case of paniya tribe of Wayanad. Unpublished M.Sc. (Ag) thesis, Kerala Agricultural University, Thrissur, 83p.

Chandrakumar, A. (2016). A Study on Social Exclusion of Adiya Tribal Community of Wayanad District, Kerala, Unpublished M.Sc. (Ag.) thesis, University of Agricultural Sciences, Karnataka, 146p.

Prabhu, P. (2011). Sustainable Tribal Development. Journal of Public Administration. 39(3): 479-487. 